\title{
SILATURRAHIM PERSPEKTIF FILSAFAT ISLAM (Ontologi, Epistemologi, Aksiologi)
}

\author{
M. Dzikrul Hakim Al Ghozali *
}

\begin{abstract}
Gathering(silaturrahim) in a language derived from two words namely silah (relationship) and Rahim (Rahim women) that have meaning nasab Relations, as the verse above says alArham (womb) is defined as the gathering(silaturrahim). But in essence the relationship is not just a relationship nasab, but further than that relationships among Muslims is part of silaturrahmi, so God mengibarat the Muslims like one body. As the word of God. "Indeed the believers are brothers, therefore make peace between your brothers and fear Allah, that ye may obtain mercy." (Al-Hujurat [49]: 10). Fraternal relationship is what makes the fellow Muslims have an obligation to help each other, mutual respect, to visit when sick, drove up to the grave when he died, pray for one another, each denounced the ban, menghasud and others.
\end{abstract}

Keywords: Philosophy and Gathering(silaturrahim).

\section{A. PENDAHULUAN}

Nabi Muhammad saw. merupakan teladan bagi setiap umat manusia dimana setiap gerak geriknya mulai dari ucapan, perbuatan maupun ketetetapannya semua menjadi tuntunan dan sumber ajaran Islam kedua setelah al-qur'an.

Adapun diantara anjuran dan ajakan Nabi Muhammad terhadap umatnya yaitu ada silaturrahim atau yang dalam bahasa Indonesia sering dikenal dengan istilah silaturahmi yang dimana silaturahmi sering diartikan dengan menyambung

*Dosen UNWAHA Tambak Beras Jombang, FAI, Prodi PBA.

Dinamika Vol. 1, No. 1, Desember 2016 | 51 


\section{Dzikrul Hakim Al Ghozali}

tali kasih sayang antara sesama karib kerabat, tetapi juga mencakup masyarakat yang lebih luas.

Kemudian dengan kita senantiasa menjalin silaturrahmi maka akan dapat memelihara hubungan yang baik antar sesama anggota keluarga maupun masyarakat luas sebab menjaga silaturrahmi juga dimasukkan Allah SWT menjadi salah satu sifat orang-orang yang mempunyai perangai mulia dan amal sholeh.

Sehingga kita sebagai muslim yang taat dan bertaqwa sangatlah wajib hukumnya bagi kita untuk senantiasa menjaga tali persaudaraan diantara kita umat Islam karena dengan senantiasa kita menjaga tali silaturrahmi maka juga akan mempermudah dalam memenuhi kebutuhan kita dalam hidup bermasyarakat. Untuk itu kajian tentang filsafat silaturahim ini perlu di sajikan dalam artikel singkat ini, namun karena keterbatasan serta alokasi waktu yang terbatas, maka artikel ini akan menguraiakan tentang hadits-hadits Nabi yang berkenaan dengan silaturrahmi sebagai media pemersatu umat. Selanjutnya pembahasan ini akan dianalisis secara filosofis (Ontologi, Epistemologi, dan Aksiologi) dari Silaturrahmi.

\section{B. PEMBAHASAN}

\section{ONTOLOGI SILATURRAHIM.}

Silaturrahmi adalah istilah yang cukup akrab dan popular di dalam pergaulan umat Islam sehari-hari, namun pada hakekatnya istilah tersebut 
merupakan bentukan dari bahasa Arab dari kata silaturrahim,dan istilah silaturrahim ini berasal dari dua kata yakni : Shilah yang berarti hubungan atau sambungan dan rahim yang memiliki arti peranakan. ${ }^{42}$

Istilah-istilah tersebut merupakan sebuah simbol hubungan baik penuh kasih sayang antar karib kerabat yang asal usulnya berasal dari satu rahim. Disini dikatakan simbol karena rahim atau peranakan secara materi tidak bisa disambung atau tidak bisa dihubungkan dengan rahim lain. Dengan kata lain, rahim yang dimaksud disini adalah qarabah atau nasab yang disatukan oleh rahim ibu, dimana hubungan antara satu dengan yang lain diikat dengan hubungan rahim.

Maka dari uraian tersebut dapat difahami bahwa pemaknaan terhadap istilah silaturrahim cenderung pada hubungan kasih sayang yang terbatas pada hubungan-hubungan dalam sebuah keluarga besar atau qarabah.

Dengan demikian istilah silaturrahim dengan istilah silaturrahmi memiliki maksud pengertian yang sama namun dalam penggunaan bahasa Indonesia istilah silaturrahmi memiliki pengertian yang lebih luas, karena penggunaan istilah ini tidak hanya terbatas pada hubungan kasih sayang antara sesama karib kerabat, akan tetapi juga mencakup pengertian masyarakat yang lebih luas. Kemudian mengadakan silaturrahmi dapat diaplikasikan dengan

\footnotetext{
${ }^{42}$ Yunahar Ilyas, Kuliah Akhlak, ( Yogyakarta : Pustaka Pelajar Offset, 2007 ), Cet. IX, hlm. 183
} 


\section{Dzikrul Hakim Al Ghozali}

mendatangi famili atau teman dengan memberikan kebaikan baik berupa ucapan maupun perbuatan. ${ }^{43}$

\section{EPISTIMOLOGI SILATURRAHIM.}

Silaturrahmi atau dapat diartikan menyambung tali kasih sayang adalah merupakan bagian dari kebutuhan setiap makhluk hidup dan yang lebih utamanya disini adalah manusia. Karena manusia merupakan "Makhluk Sosial" yakni makhluk yang membutuhkan hidup bersama hal ini terbukti dengan adanya dalam memenuhi kebutuhannya manusia tidak mampu sendirian meskipun pada saat sekarang ini teknologi sudah sangat mengalami perkembangan dan kemajuan, oleh karena itu maka tidak bisa dipungkiri lagi bahwa manusia harus senantiasa menjaga hubungan yang baik dengan orang lain.

Kasih sayang merupakan sifat Allah yang sangat banyak disebutkan dalam al-qur'an. Dengan demikian maka kita sebagai manusia yang taat, percaya dan bertaqwa kepada-Nya, tentu harus berupaya untuk meneladani sifat keutamaan Allah tersebut dalam menjalani kehidupan, karena sesuai janjiNya, Allah akan menjadikan kasih sayang ada di dalam hati orang-orang beriman dan beramal sholeh. ${ }^{44}$

Sebagaimana firman-Nya dalam surat Maryam ayat 96 sebagi berikut :

\footnotetext{
${ }^{43}$ Hussein Bahresi, Hadits Shohih Bukhari-Muslim ( Surabaya : Karya Utama, Tt), hlm 140

${ }^{44}$ Juwariyah, Hadits Tarbawi, ( Yogyakarta : Teras, 2010 ), Cet. I hlm. 48
} 


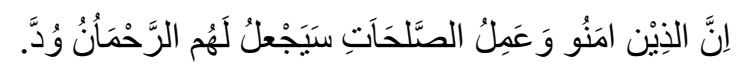

Artinya : Sesungguhnya orang-orang yang beriman dan beramal sholeh, yang Maha Rahman (Allah SWT) akan mengadakan perasaan kasih sayang bagi sesamanya.

Dimana dari ayat tersebut dapat kita fahami secara logika bahwa setiap mukmin seharusnya hidup berdampingan dengun penuh kasih, karena Allah SWT telah memberi masing-masing manusia sifat kasih saying, namun di dalam realitanya pada masa sekarang adalah penuh dengan permusuhan, pertikaian, perselisihan, dan sifat-sifat tidak terpuji lainnya, hal itu mencerminkan betapa minimnya sifat kasih sayang pada masa sekarang ini.

Sedangkan Islam dalam berbagai ayat al-qur'an maupun hadits Nabi sebagai sumber ajaran Islam juga telah banyak menganjurkan akan pentingnya kasih sayang terhadap sesama, serta melarang sifat yang berbau permusuhan dan pertikaian.

Oleh karena itu Allah sangat menjunjung tinggi orang yang memiliki sifat kasih sayang terhadap sesama, karena jika seseorang telah memiliki sifat kasih sayang terhadap sesamanya, maka Allah akan mengasihinya dan kasih sayang Allah SWT tersebut akan diletakkan dihati para Malaikat dan semua anak Adam, sehingga para Malaikat dan semua anak manusia akan mengasihi orang yang memberikan kasihnya kepada orang lain dan begitu pula sebaliknya. ${ }^{45}$

\footnotetext{
${ }^{45} \mathrm{Ibid}$, hlm. 50
} 


\section{Dzikrul Hakim Al Ghozali}

Dengan demikian maka menyambung tali silaturrahmi akan dapat menjadi sarana kelapangan rizki dan panjangnya umur. Hal itu sebagaimana hadits Nabi :

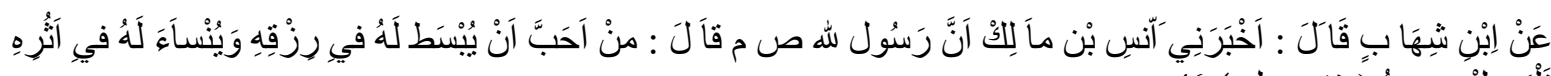

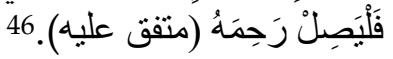

Artinya : dari Ibnu Syihab, dari Annas bin Malik berkata bahwa sesungguhnya Rasulullah saw bersabda: Barang siapa ingin dilapangkan rizkinya dan ditangguhkan atau dipanjangkan umurnya, maka hendaklah dia menyambung tali kasih dengan keluarganya.(H.R. Bukhori Muslim).

Dari kutipan hadits tersebut dapat difahami bahwa bahwa menyambung tali persaudaraan atau kekeluargaan akan mendatangkan kelapangan rizki dan panjang umur.

Di lapangkan rizki dari kutipan hadits tersebut dapat difahami secara obyektif, karena salah satu modal untuk mendapatkan rizki adalah dengan kita berhubungan baik dengan sesama manusia, peluang-peluang bisnis misalnya akan terbuka dari banyaknya hubungan kita dengan masyarakat luas, bahkan jika kita lihat pada realita sekarang kepercayaan rekanan bisnis adalah lebih diutamakan daripada yang lainya.

Sedangkan maksud dari pengertian dipanjangkan umur bisa dalam pengertian sebenarnya yakni ditambah umurnya dari yang sudah ditentukan Allah SWT atau dipanjangkan umurnya disini hanya sebatas dalam pengertian simbolis, yang menunjukkan bahwa umur yang mendapat taufiq dari Allah SWT

${ }^{46}$ Imam Abi Zakariya, Riyadhu Asshalihin, Terj. Ahmad Sunarto, ( Jakarta : Pustaka Amani,1999 ) juz I hlm 329 
sehingga berkah dan bermanfaat bagi umat manusia sehingga namanya akan abadi dan akan senantiasa dikenang dalam waktu yang lama. ${ }^{47}$

Meskipun menyambung bukanlah sekedar mengimbangi kebajikan yang telah dilakukan oleh sanak keluarga akan tetapi penyambung tali kekeluargaan adalah orang yang ketika ada keluarga yang karena suatu sebab seseorang tersebut memutuskan hubungan kekeluargaan dengannya, dia sanggup dan bersedia untuk memperbaiki dan menyambung tali yang telah diputuskan tersebut.

Dalam sebuah hadits yang diriwayatkan Bukhari Muslim dikatakan bahwa rahim atau kasih sayang dalam arti lain kekeluargaan itu sudah tergantung di Arsy, dimana siapa yang menyambungnya dengan Dia, maka Allah pun akan menyambungnya dan begitu pula sebaliknya siapa yang memutuskan Allah, Allah juga akan memutusnya. ${ }^{48}$ Dan bunyi hadits tersebut yaitu :

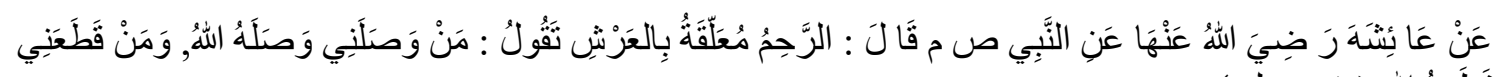

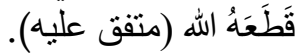

Artinya : Dari Aisyah r.a dari Nabi saw bersabda : Rahim atau kekeluargaan itu tergantung di Arsy. Rahim itu berkata : barang siapa menyambungku Allah akan menyambungnya, dan barang siapa memutusku maka Allah akan memutuskan hubungan dengan dia. (H.R. Bukhari dan Muslim). ${ }^{49}$

\footnotetext{
${ }^{47}$ Yunahar Ilyas, Kuliah Akhlak, hlm 190

${ }^{48}$ Juwariyah, Hadits Tarbawi, hlm 51

${ }^{49}$ Imam Abi Zakariya, Riyadhu Asshalihin, hlm 332
} 


\section{Dzikrul Hakim Al Ghozali}

Ketika seorang umat mengupayakan dirinya untuk memutuskan tali silaturrahmi maka akan hilanglah keharmonisan sebuah persahabatan atau persaudaraan, sehingga yang tinggal hanyalah kegalauan dalam hidup karena ketika dia putuskan hubungan dengan keluarga maka Allah pun akan memutuskan hubungan dengannya.

Ketika Allah sudah memutuskan hubungan dengan hamba-Nya maka tidak ada yang terjadi dalam diri hamba tersebut kecuali penderitaan, namun jika seorang hamba memiliki hubungan yang harmonis dengan Allah sebagai pencipta dan pemiliknya maka hanya kebahagiaan dan ketentraman yang dia rasakan, oleh karena itu maka tidak heran jika suatu ketika seorang sahabat meminta kepada Nabi untuk ditunjukkan terhadap amalan yang dapat memasukkan kesurga, dan Nabi pun mengatakan bahwa salah satunya adalah menyambung tali persaudaraan. Adapun bunyi Haditsnya adalah sebagai berikut :

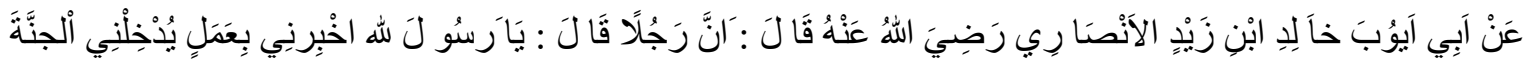

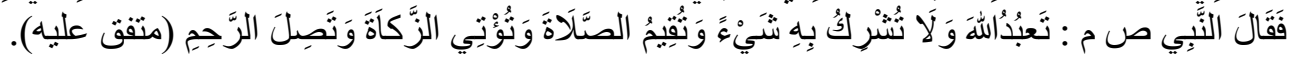

Artinya : Dari Ayyub Khalid bin Zaid Al- Anshariy ra. Ia berkata : ada seseorang bertanya kepada Rasulullah: "Wahai Rasulullah, beritahukanlah kepadaku amal yang dapat memasukkanku kedalam surga. "Nabi saw menjawab : sembahlah Allah dan jangan mempersekutukan-Nya, dirikanlah salat, bayarlah zakat, dan sambunglah tali kekerabatan." 50 (H.R. Bukhari dan Muslim).

Maka dari kutipan hadits riwayat Bukhari dan Muslim diatas dengan jelas dapat kita fahami bahwa secara tegas Nabi menyampaikan bahwa silarurrahmi termasuk amalan yang dapat memasukkan seseorang kedalam surga Allah,

${ }^{50}$ Ibid, hlm 337-338 
apabila orang tersebut beriman, mendirikan shalat, dan memberikan hak fakir miskin dengan mengeluarkan zakat.

Namun perihal keterangan-keterangan Hadits Larangan Memutus Tali Kasih, Nabi Muhammad saw bersabda :

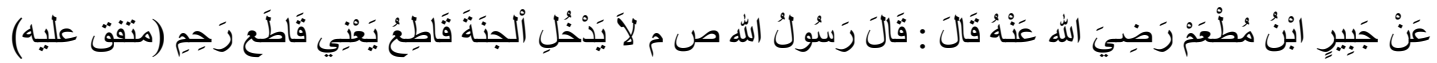

Artinya : Jabir bin Muth'im berkata : Rasulullah saw. bersabda: "tidak masuk syurga siapa yang memutuskan tali kasih sayangnya dengan orang lain“. ${ }^{51}$

Adapun yang dimaksud dengan " tidak masuk" dalam kutipan hadits tersebut adalah tidak langsung masuk karena umat manusia akan masuk syurga dengan syafaat Rasulullah saw. Dan orang yang sekali saja mengucapkan Syahadatain selama hidupnya dan matinya tidak kafir. Hadits diatas bersifat tahdiidan atau ancaman berat bagi siapa saja yang memutuskan tali silaturrahminya.

Dari uraian hadits diatas jelas bahwa orang yang memutuskan hubungan persaudaraan berarti dia telah berbuat maksiat karena telah melanggar perintah Allah SWT dan Rasul-Nya tentang kewajiban umat Islam untuk menyambung tali persaudaraan. Bahkan sekedar menjauhi dan meninggalkan saudaranya lebih dari tiga malam dengan niat memutuskan hubungan persaudaraan pun tidak dibenarkan oleh agama.

Dalam suatu hadits Rasulullah saw pernah bersabda:

\footnotetext{
${ }^{51}$ Hafizh Ibnu Hajar, Bulughul Maram, Terj. Kahar Masyhur, ( Jakarta : Rineka Cipta, 1992) Jilid II, hlm. 372
} 


\section{Dzikrul Hakim Al Ghozali}

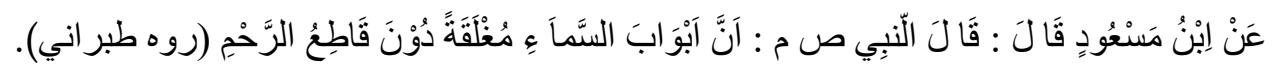

Artinya : Dari Ibnu Mas'ud r.a berkata : Nabi Muhammad saw bersabda : Sesungguhnya pintu langit itu tertutup untuk orang yang memutuskan hubungan persaudaraan. (H.R. Thabrani).

Dan Rasulullah saw dalam berbagai haditsnya pun telah mengutuk perbuatan dari orang-orang yang memutuskan tali silaturrahmi atau hubungan persaudaraan, yang dimana secara tegas diperintah oleh Allah SWT untuk senantiasa menjaganya, sebab yang demikian dapat difahami karena kecintaan seseorang terhadap saudaranya merupakan bukti dari keimanan seseorang sehingga ketika seseorang telah memutuskan hubungan kasih sayang terhadap sesama sebagai bentuk persaudaraan maka dia telah kehilangan sebagian dari keimanannya,karena keimanan yang sempurna menuntut kecintaan terhadap sesama muslim. ${ }^{52}$

\section{AKSIOLOGI SILATURRAHIM.}

Silaturahmi secara konkrit dapat diwujudkan dalam bentuk-bentuk antara lain sebagai berikut :

1. Berbuat baik atau ihsan terutama dengan memberikan bantuan materiil untuk memenuhi kebutuhan hidupnya, adapun yang harus diprioritaskan untuk dibantu adalah karib kerabat dibanding dengan pihak-pihak lain

\footnotetext{
${ }^{52}$ Juwariyah, Hadits Tarbawi, hlm, 55
}

60 | Dinamika Vol. 1, No. 1, Desember 2016 
yakni diantaranya ada anak yatim, orang miskin, ibnu sabil, dan lain-lain. Karena jika karib kerabat tersebut seorang yang miskin maka bersedekah kepada kerabat tersebut bermakna ganda ; yakni sedekah sekaligus silaturrahmi. ${ }^{53}$ Dengan demikian jelas bahwa dari ukhuwah antar karib kerabat adalah lebih utama.

2. Memelihara dan meningkatkan rasa kasih sayang sesama kerabat maupun sesama muslim maupun orang lain dapat dapat diaplikasikan dengan sikap saling kenal-mengenal, hormat-menghormati, bertukar salam, kunjungmengunjungi, surat-menyurat, bertukar hadiah, jenguk-menjenguk, bantumembantu, dan berkerja sama menyelenggarakan walimahan, dan lainlain. ${ }^{4}$

Dan itu semua bisa dikatakan silaturrahmi dengan catatan hal-hal tersebut diorientasikan untuk meningkatkan persaudaraan. Kemudian selain dapat meningkatkan dan mempererat hubungan persaudaraan antara sesama karib kerabat pada khususnya dan masyarakat luas pada umumnya, silaturrahmi juga dapat member manfaat lain baik di dunia maupun akhirat. Dan diantara manfaat lain itu adalah :

1. Mendapat rahmat, nikmat, dan ihsan dari Allah SWT

Sebagaimana penjelasaan hadits yang telah dikumukakan dibagian awal bahwa barang siapa yang menyambung rahim atau tali persaudaraan maka

\footnotetext{
${ }^{53}$ Yunahar Ilyas, Kuliah Akhlak, hlm.185
}

${ }^{54}$ Ibid, hlm. 187 


\section{Dzikrul Hakim Al Ghozali}

Allah SWT pun juga akan menghunghubungkannya namun begitu pula sebaliknya, karena menurut sebagian ulama, hakikat dari silaturrahmi adalah al-'athfu wa ar-rahmah yang berarti lemah lembut dan kasih sayang. Dan shilatullah dengan hamba-hamba-Nya.'Athfullah berarti ihsan dan nikmat-Nya.

Dengan demikian maka orang-orang yang melakukan silaturrahmi akan mendapatkan rahmat, nikmat, dan ihsan dari Allah SWT.

2. Masuk surga dan jauh dari neraka

Secara khusus disebut oleh Rasulullah saw bahwa sesudah amalan pokok, silaturrahmi dapat mengantarkan seseorang ke seseorang ke surga dan menjauhkan dari neraka sebagaimana hadits riwayat Imam Bukhari dan Muslim yang diriwayatkan oleh Abu Ayyub ibn Zaid al-Ansari sebagai berikut:

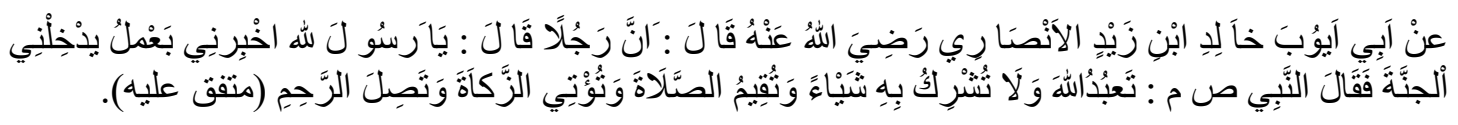

Artinya : Dari Ayyub Khalid bin Zaid Al- Anshariy ra. Ia berkata : ada seseorang bertanya kepada Rasulullah: "Wahai Rasulullah, beritahukanlah kepadaku amal yang dapat memasukkanku kedalam surga. "Nabi saw menjawab: "sembahlah Allah dan jangan mempersekutukan-Nya, dirikanlah salat, bayarlah zakat, dan sambunglah tali kekerabatan."55 (H.R. Bukhari dan Muslim).

3. Lapang rizki dan panjang umur

Secara lebih konkret Rasulullah saw menjanjikan rizki yang lapang dan umur yang panjang bagi orang-orang yang melakukan sillaturrahmi sebagaimana sabda beliau :

${ }^{55}$ Juwariyah, Hadits Tarbawi, hlm 337-338

62 | Dinamika Vol. 1, No. 1, Desember 2016 


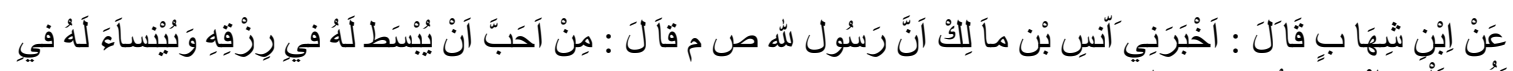

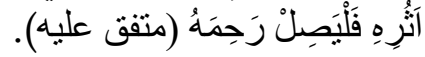

Artinya : dari Ibnu Syihab, dari Annas bin Malik berkata bahwa sesungguhnya Rasulullah saw bersabda : barang siapa ingin dilapangkan rizkinya dan ditangguhkan atau dipanjangkan umurnya, maka hendaklah dia menyambung tali kasih dengan keluarganya.

\section{KESIMPULAN}

Dari uraian-uraian tersebut maka dapat kita ketahui ontologinya bahwa silaturrahim dengan silaturrahmi memiliki maksud pengertian yang sama namun dalam penggunaan bahasa Indonesia istilah silaturrahmi memiliki pengertian yang lebih luas, karena penggunaan istilah ini tidak hanya terbatas pada hubungan kasih sayang antara sesama karib kerabat, akan tetapi juga mencakup pengertian masyarakat yang lebih luas.

Sedangkan epistemologinya bahwa Islam dalam berbagai ayat al-qur'an maupun hadits Nabi sebagai sumber ajaran Islam juga telah banyak menganjurkan akan pentingnya kasih sayang terhadap sesama, serta melarang sifat yang berbau permusuhan dan pertikaian. sehingga Allah SWT pun sangat menjunjung tinggi orang yang memiliki sifat kasih sayang terhadap sesama, karena jika seseorang telah memiliki sifat kasih sayang terhadap sesamanya, maka Allah SWT akan mengasihinya. Dan orang-orang yang memutuskan hubungan persaudaraan berarti dia telah berbuat maksiat karena telah melanggar perintah Allah SWT dan Rasul-Nya tentang kewajiban umat Islam untuk menyambung tali persaudaraan dan Rasulullah saw dalam berbagai 


\section{Dzikrul Hakim Al Ghozali}

haditsnya pun juga telah mengutuk perbuatan dari orang-orang yang memutuskan tali silaturrahmi atau hubungan persaudaraan, yang dimana secara tegas diperintah oleh Allah SWT untuk senantiasa menjaganya.

Adapun aksiologinnya yaitu bahwa dengan senantiasa menyambung silaturrahmi maka kita akan memperoleh banyak manfaat diantaranya yaitu : akan mendapat rahmat, nikmatdan ihsan dari Allah SWT, masuk surga dan jauh dari neraka serta akan dilapangkan rizki dan panjang umur.

\section{SARAN}

Dengan mengucapkan rasa syukur kepada Allah yang telah melimpahkan rahmat, taufik, hidayat, serta inayah-Nya sehingga kami dapat menyelesaikan artikel ini, semoga uraian-uraian yang kami sampaikan dalam artikel ini dapat bermanfaat bagi kami sendiri dan para pembaca. Amiin. 


\section{DAFTAR KEPUSTAKAAN}

Abi Zakariya, Imam, Riyadhu Asshalihin, Terj. Ahmad Sunarto, (Jakarta : Pustaka Amani,1999) juz I

Bahresi, Hussein, Hadits Shohih Bukhari-Muslim ( Surabaya : Karya Utama, Tt)

Ibnu Hajar, Hafidz, Bulughul Maram, Terj. Kahar Masyhur, ( Jakarta : Rineka Cipta, 1992) Jilid II

Ilyas, Yunahar, Kuliah Akhlak, ( Yogyakarta : Pustaka Pelajar Offset, 2007), Cet. IX,

Juwariyah, Hadits Tarbawi, ( Yogyakarta : Teras, 2010 ), Cet. I 


\section{Dzikrul Hakim Al Ghozali}

66 | Dinamika Vol. 1, No. 1, Desember 2016 